\title{
Catalytic Combustion of Low Concentration Methane over Catalysts Prepared from Co/Mg-Mn Layered Double Hydroxides
}

\author{
Hongfeng Liu, ${ }^{1,2}$ Xingrui Fu, ${ }^{1,2}$ Xiaole Weng, ${ }^{1,2}$ Yue Liu, \\ Haiqiang Wang, ${ }^{1,2}$ and Zhongbiao $\mathrm{Wu}^{1,2}$ \\ ${ }^{1}$ Department of Environmental Engineering, Zhejiang University, Zijingang Campus, Yuhangtang Road 388, \\ Hangzhou 310058, China \\ ${ }^{2}$ Zhejiang Provincial Engineering Research Center of Industrial Boiler \& Furnace Flue-Gas Pollution Control, \\ Hangzhou 310058, China
}

Correspondence should be addressed to Xiaole Weng; xlweng@zju.edu.cn and Yue Liu; yueliu@zju.edu.cn

Received 22 May 2014; Accepted 4 June 2014; Published 1 July 2014

Academic Editor: Fan Dong

Copyright (C) 2014 Hongfeng Liu et al. This is an open access article distributed under the Creative Commons Attribution License, which permits unrestricted use, distribution, and reproduction in any medium, provided the original work is properly cited.

\begin{abstract}
A series of $\mathrm{Co} / \mathrm{Mg}-\mathrm{Mn}$ mixed oxides were synthesized through thermal decomposition of layered double hydroxides (LDHs) precursors. The resulted catalysts were then subjected for catalytic combustion of methane. Experimental results revealed that the $\mathrm{Co}_{4.5} \mathrm{Mg}_{1.5} \mathrm{Mn}_{2} \mathrm{LDO}$ catalyst possessed the best performance with the $T_{90}=485^{\circ} \mathrm{C}$. After being analyzed via XRD, BET-BJH, SEM, $\mathrm{H}_{2}$-TPR, and XPS techniques, it was observed that the addition of cobalt had significantly improved the redox ability of the catalysts whilst certain amount of magnesium was essential to guarantee the catalytic activity. The presence of Mg was helpful to enhance the oxygen mobility and, meanwhile, improved the dispersion of Co and Mn oxides, preventing the surface area loss after calcination.
\end{abstract}

\section{Introduction}

Low concentration methane such as coal mine methane is usually emitted directly into the atmosphere or burned immediately due to its low calorific value, resulting in either greenhouse effect or a huge waste of resource. Moreover, $\mathrm{NO}_{x}$ can be also produced during thermal combustion. Therefore, it is necessary to develop a cost-effective technology for capturing and utilizing the low concentration methane.

So far, a number of studies have focused on the catalytic oxidation of methane, especially on the noble metal catalysts [1-4]. Nevertheless, noble metal catalysts normally show some shortcomings for real application like volatility, high sintering rates, poisoning in the presence of disturbing compounds, and high price [5]. As such, the mixed metal oxide catalysts have been attracting rising concern recently for methane catalytic combustion [6,7]. And some reporter showed that the activity of mixed metal oxide catalysts was not necessarily worse than noble metal catalysts for VOCs catalytic oxidation [8-10].
Layered double hydroxides (LDHs) are known as a series of anion layered compounds whose chemical composition can be represented as $\left[\mathrm{M}_{1-x}^{\mathrm{II}} \mathrm{M}_{x}^{\mathrm{III}}(\mathrm{OH})_{2}\right]^{x+}\left[\mathrm{A}_{x / n}^{n} \cdot y \mathrm{H}_{2} \mathrm{O}\right]^{x-}$. $\mathrm{M}^{\mathrm{II}}$ and $\mathrm{M}^{\mathrm{III}}$ are bivalent and trivalent metal cations, $\mathrm{A}^{n-}$ is an $n$-valent anion, and the values of $x$ usually range from 0.20 to 0.33 . After thermal decomposition, LDHs could be potential materials for total oxidation catalysts due to their large surface area, high metal dispersion, small crystallite size, and stability against sintering [11]. Up to now, a lot of efforts have been dedicated to developing the LDHs catalysts for volatile organic compounds (VOCs) degradation and the methane catalytic combustion $[5,12]$.

In light of the above points, we synthesized a series of LDHs related catalysts, in which the transition metals Co and $\mathrm{Mn}$ were induced as bivalent and trivalent metal cations, respectively, for the methane catalytic combustion. Then, the catalysts were characterized by various methods to show the relationships between the chemophysical properties of the catalysts and their performances. 


\section{Experimental Section}

2.1. Catalyst Preparation. The LDHs precursors $\mathrm{Co} / \mathrm{Mg}-\mathrm{Mn}$ were prepared by coprecipitation method at a constant $\mathrm{pH}$ value $(10 \pm 0.5)$. Mixed salt solution $(100 \mathrm{~mL})$ and $2 \mathrm{M} \mathrm{NaOH}$ $(100 \mathrm{~mL})$ solution were added dropwise into $100 \mathrm{~mL} 0.45 \mathrm{M}$ $\mathrm{Na}_{2} \mathrm{CO}_{3}$ solution simultaneously under vigorous mechanical stirring at $60^{\circ} \mathrm{C}$ in water bath for $1 \mathrm{~h}$. The mixed salt solution consists of a total cation concentration of $2 \mathrm{M}$ from $\mathrm{Mg}\left(\mathrm{NO}_{3}\right)_{2} \cdot 6 \mathrm{H}_{2} \mathrm{O}, \mathrm{Co}\left(\mathrm{NO}_{3}\right)_{2} \cdot 6 \mathrm{H}_{2} \mathrm{O}$, and $\mathrm{Mn}\left(\mathrm{NO}_{3}\right)_{2}$ with $(\mathrm{Mg}+\mathrm{Co}) / \mathrm{Mn}=3.0$. The addition of the alkaline solution and the $\mathrm{pH}$ value were controlled by a $\mathrm{pH}$ meter. Precipitates formed were aged with the mother liquid overnight at $60^{\circ} \mathrm{C}$ under vigorous stirring and then filtered and thoroughly washed with distilled water to $\mathrm{pH}=7.0$. After that, the resulting solid (LDHs precursors) was dried at $100^{\circ} \mathrm{C}$ for $12 \mathrm{~h}$. Then, these LDHs precursors (denoted as $\mathrm{Co}_{x} \mathrm{Mg}_{6-x} \mathrm{Mn}_{2} \mathrm{LDH}$ ) were calcined at $600^{\circ} \mathrm{C}$ for $4 \mathrm{~h}$ to derive $\mathrm{Co} / \mathrm{Mg}$-Mn mixed oxide catalysts (denoted as $\mathrm{Co}_{x} \mathrm{Mg}_{6-x} \mathrm{Mn}_{2} \mathrm{LDO}$ ). Finally, the oxide catalysts were crushed and sized in 40-60 mesh for activity test and characterizations.

2.2. Catalytic Activity Testing. The catalytic activity tests of methane were performed in a fixed bed with an inside steel tube reactor operated at atmospheric pressure. $0.5 \mathrm{~g}$ catalyst diluted with equal volume silica sand was used during the test with a gas mixture of $\mathrm{CH}_{4}: \mathrm{O}_{2}: \mathrm{N}_{2}=1.6: 16: 144$ at a total flow rate of around $160 \mathrm{~mL} / \mathrm{min}$ passing through the reactor. The gas flow rate was controlled by mass flow meter. The internal diameter of the reactor is $8.20 \mathrm{~mm}$ and the length is $450 \mathrm{~mm}$. Catalytic activity tests were carried out with a gas hourly space velocity (GHSV) of $25,000 \mathrm{~h}^{-1}$, at the temperature ranging from 350 to $600^{\circ} \mathrm{C}$. The reactants and products were online analyzed by Agilent GC and equipped with flame ionization detection (FID). Before each test, the catalysts were preheated at $500^{\circ} \mathrm{C}$ for $30 \mathrm{~min}$ and then cooled to $350^{\circ} \mathrm{C}$ to start the test. The methane conversion rate was calculated based on the integrated GC peak areas.

2.3. Catalytic Characterization. X-ray diffraction patterns (XRD) were recorded using a Rigaku D/Max RA diffractometer to identify the crystal structure of the samples with the monochromatic $\mathrm{Cu} \mathrm{K} \alpha$ radiation at $2 \theta$ ranging from 5 to $80^{\circ}$ with a scanning rate of $4^{\circ} / \mathrm{min}$. The textural properties of the derived oxides were analyzed by $\mathrm{N}_{2}$ adsorption/desorption at $77 \mathrm{~K}$ in a JW-BK132F static adsorption analyzer. Before each test, the catalyst was pretreated at $100^{\circ} \mathrm{C}$ for $3 \mathrm{~h}$ in vacuum. The specific surface area was calculated with the BET equation, and the pore volume and pore size distribution were obtained by the BJH method. The micromorphology characteristics were examined by scanning electron microscope (SEM: Ultra 55, Carl Zeiss AG, USA). A custom-made TCD setup was employed to run the temperature programmed reduction (TPR) test by using $50 \mathrm{mg}$ catalysts. Prior to the test, a preheat treatment was performed in $5 \% \mathrm{O}_{2} / \mathrm{He}$ at $500^{\circ} \mathrm{C}$ for $2 \mathrm{~h}$. Then, the sample was cooled down to $100^{\circ} \mathrm{C}$ and kept at this temperature for $30 \mathrm{~min}$. After that, TPR tests were carried out at a heating rate of $10^{\circ} \mathrm{C} / \mathrm{min}$ with $30 \mathrm{~mL} / \mathrm{min}$

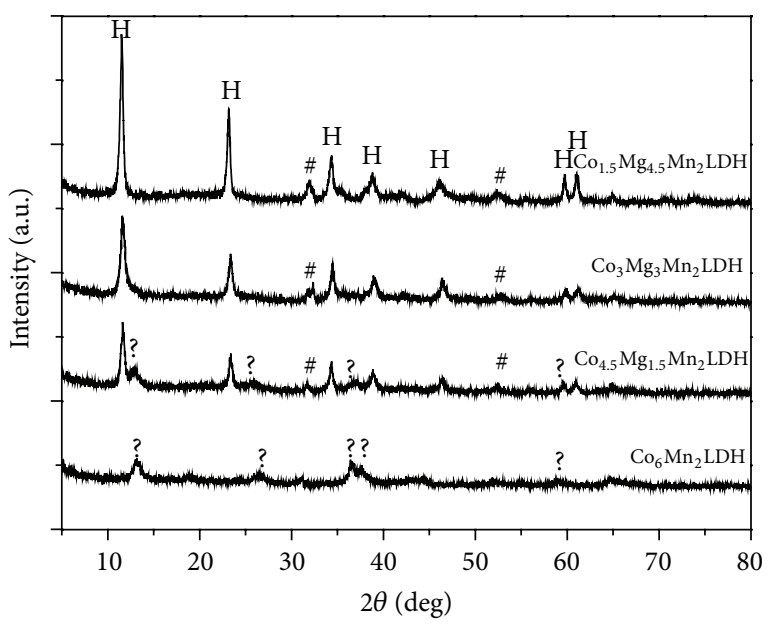

FIGURE 1: XRD patterns of the $\mathrm{Co}_{x} \mathrm{Mg}_{6-x} \mathrm{Mn}_{2} \mathrm{LDH}$ precursors ( $\mathrm{H}$ : hydrotalcite-like compounds; $\#$ : $\mathrm{MnCO}_{3}$; ?: unidentified phases).

$6 \% \mathrm{H}_{2}$ balanced with $\mathrm{He}$ going through. X-ray photoelectron spectroscopy with $\mathrm{Al} \mathrm{K} \alpha \mathrm{X}$-ray $(\mathrm{h} \nu=1486.6 \mathrm{eV})$ radiation operated at $150 \mathrm{~W}$ (Thermo ESCALAB 250Xi, USA) was used to investigate the surface atomic state of the sample. All the binding energies obtained were corrected using the $\mathrm{C} 1 \mathrm{~s}$ level at $284.8 \mathrm{eV}$ as an internal standard.

\section{Results and Discussions}

XRD patterns of all the $\mathrm{Co}_{x} \mathrm{Mg}_{6-x} \mathrm{Mn}_{2} \mathrm{LDH}$ precursors and calcined mixed oxides are exhibited in Figures 1 and 2, respectively. From Figure 1, a well-crystallized LDHs phase $\left(2 \theta=11.5^{\circ}, 23^{\circ}, 34^{\circ}\right)$ could be detected in all the samples except the $\mathrm{Co}_{6} \mathrm{Mn}_{2} \mathrm{LDH}$. Meanwhile, the reflections corresponding to $\mathrm{MnCO}_{3}$ (PDF-No. 44-1472) also appeared in the former three samples [13]. However, the intensity referred to $\mathrm{Co}_{6} \mathrm{Mn}_{2} \mathrm{LDH}$ sample was particularly low. And its crystallized phases could not be identified based on the phase analysis software, Jade5. The similar finding had been also reported by Kovanda et al. [14] in their study regarding $\mathrm{Co}$ and $\mathrm{Mn}$ containing layered double hydroxides. After calcination at $600^{\circ} \mathrm{C}$ for $4 \mathrm{~h}$, spinel-type mixed oxides were formed in all the samples including $\mathrm{Co}_{6} \mathrm{Mn}_{2} \mathrm{LDO}$. Such samples probably consist of one or mixture of $\mathrm{MnCo}_{2} \mathrm{O}_{4}$ (PDF number: 23-1237), $\mathrm{CoMn}_{2} \mathrm{O}_{4}$ (PDF number: 01-1126), $\mathrm{Mg}_{6} \mathrm{MnO}_{8}$ (PDF number: 19-0766), $\mathrm{Co}_{3} \mathrm{O}_{4}$ (PDF number: 43-1003), and $\mathrm{MgCoMnO}_{4}$ (PDF number: 39-1157), considering that their peaks were almost superimposed. At low Co loading content $\left(\mathrm{Co}_{1.5} \mathrm{Mg}_{4.5} \mathrm{Mn}_{2} \mathrm{LDO}\right), \mathrm{MnCo}_{2} \mathrm{O}_{4}$ could be the main phase. And, with the increase of Co content, the peaks would gradually shift to higher angle range. For the sample $\mathrm{Co}_{6} \mathrm{Mn}_{2} \mathrm{LDO}$, the obtained phases were mainly $\mathrm{Co}_{3} \mathrm{O}_{4}$ phase. Compared with the other three samples, it could be also found that the signal of $\mathrm{Mg}$-free sample $\left(\mathrm{Co}_{6} \mathrm{Mn}_{2} \mathrm{LDO}\right)$ became sharper and higher, indicating that the primary particle size was probably larger than the others. For instance, the primary particle size calculated by Scherrer 


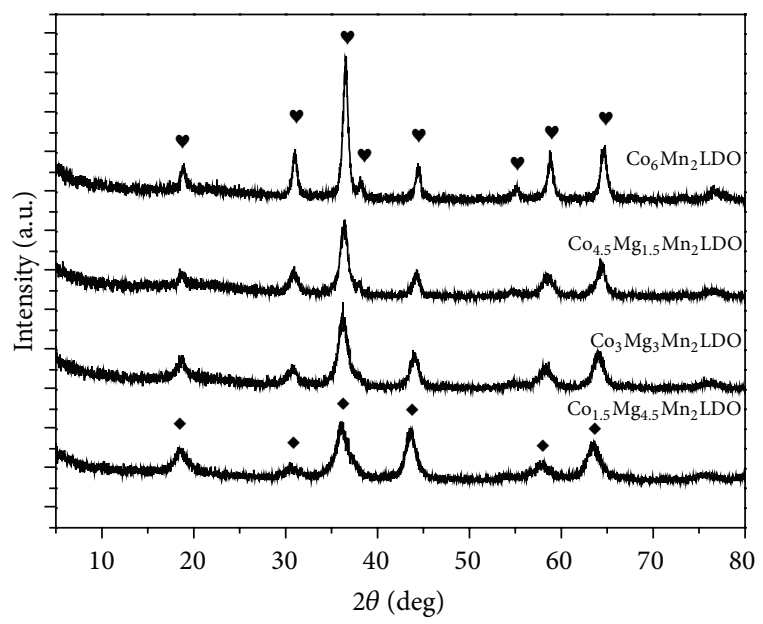

FIGURE 2: XRD patterns of the $\mathrm{Co}_{x} \mathrm{Mg}_{6-x} \mathrm{Mn}_{2} \mathrm{LDO}$ samples ( $\mathrm{MnCo}_{2} \mathrm{O}_{4}$ phases; $\bullet: \mathrm{Co}_{3} \mathrm{O}_{4}$ ).

equation increased from $8.1 \mathrm{~nm}$ for $\mathrm{Co}_{4.5} \mathrm{Mg}_{1.5} \mathrm{Mn}_{2} \mathrm{LDO}$ to $12.9 \mathrm{~nm}$ for $\mathrm{Co}_{6} \mathrm{Mn}_{2} \mathrm{LDO}$.

From the activity tests (which will be discussed in Figure 6), we found that the activity of $\mathrm{Co}_{6} \mathrm{Mn}_{2} \mathrm{LDO}$ sample was lower than the $\mathrm{Mg}$-containing sample $\mathrm{Co}_{4.5} \mathrm{Mg}_{1.5} \mathrm{Mn}_{2} \mathrm{LDO}$. To further investigate the reason, we tried to get a clue from the SEM images of their $\mathrm{Co}_{x} \mathrm{Mg}_{6-x} \mathrm{Mn}_{2} \mathrm{LDH}$ precursors. The results are shown in Figure 3. From Figures 3(a) and 3(c), the $\mathrm{Co}_{4.5} \mathrm{Mg}_{1.5} \mathrm{Mn}_{2} \mathrm{LDH}$ samples showed a flake-like morphology and the size of flakes was approximately $400-450 \mathrm{~nm}$. Without addition of magnesium, the sheet structure also appeared in the precursors, but the size and thickness grew larger. At the same time, we could also observe a lot of sintered particles from the image. This was probably attributed to the aggregation of the primary particles, since $\mathrm{Mg}$-free sample should be of smaller primary particle size according to the $\mathrm{XRD}$ results in Figure 1. And the aggregation of the particles would lead to the easy sintering of the calcined oxides. This was consistent with the results of the LDO-XRD (Figure 2).

The specific areas of the $\mathrm{Co}_{x} \mathrm{Mg}_{6-x} \mathrm{Mn}_{2} \mathrm{LDH}$ precursors and the derived LDO samples are presented in Table 1. It could be observed that the surface area of $\mathrm{LDH}$ increased from $49.09 \mathrm{~m}^{2} / \mathrm{g}$ to $130.88 \mathrm{~m}^{2} / \mathrm{g}$, which was in accordance with the result of LDH-XRD (Figure 1) that the peaks of the samples were getting broader with the addition of Co, indicating the decreasing of the grain size. However, the $\mathrm{Mg}$-free LDO sample got the greatest loss in surface area (from 130.88 to about $45 \mathrm{~m}^{2} / \mathrm{g}$ ), together with the decreases of the pore diameter and volume. This fitted well with the result of LDO-XRD (see Figure 2) that the grain size would grow bigger without $\mathrm{Mg}$ being involved. According to the literatures [15-17], the alkaline earth could isolate transition metals effectively by strong interaction to reduce the agglomeration of the particles, thus reducing the loss of the specific area after calcination.

$\mathrm{H}_{2}$-TPR (see Figure 4) showed the differences in reducibility of the prepared LDO samples caused by the
TABLE 1: Porous properties of the $\mathrm{Co}_{x} \mathrm{Mg}_{6-x} \mathrm{Mn}_{2} \mathrm{LDH}$ (a) and LDO (b).

\begin{tabular}{lcccc}
\hline Sample & $S_{\text {BET }}{ }^{\mathrm{a}}\left(\mathrm{m}^{2} / \mathrm{g}\right)$ & $S_{\text {BET }}{ }^{\mathrm{b}}\left(\mathrm{m}^{2} / \mathrm{g}\right)$ & $D_{p}{ }^{\mathrm{b}}(\mathrm{nm})$ & $V_{p}^{\mathrm{b}}\left(\mathrm{cm}^{3} / \mathrm{g}\right)$ \\
\hline$x=1.5$ & 49.09 & 43.88 & 28.66 & 0.31 \\
$x=3$ & 58.07 & 44.1 & 26.37 & 0.29 \\
$x=4.5$ & 85.15 & 50.87 & 24.36 & 0.28 \\
$x=6$ & 130.89 & 45.23 & 20.11 & 0.23 \\
\hline
\end{tabular}

increasing content of Co. Based on the literatures [18, 19], the broad reduction peaks from 250 to $500^{\circ} \mathrm{C}$ were the results of overlapping peaks related to the reductions of $\mathrm{Co} / \mathrm{Mn}$ oxides, which consists of the reduction process of $\mathrm{Co}^{\mathrm{III}} \rightarrow \mathrm{Co}^{\mathrm{II}} \rightarrow \mathrm{Co}^{0}$ in $\mathrm{Co}_{3} \mathrm{O}_{4}$ phase and $\mathrm{Mn}^{\mathrm{IV}}$ species reduction. With the increase of Co content, the peaks first shifted to higher temperature and then the peaks shifted obviously to the lower temperature and a shoulder peak appeared at $284^{\circ} \mathrm{C}$, which could be assigned to the reduction of $\mathrm{Co}^{\mathrm{III}} \rightarrow \mathrm{Co}^{\mathrm{II}}[18]$, while, for the catalyst $\mathrm{Co}_{6} \mathrm{Mn}_{2} \mathrm{LDO}$, the peaks shifted to higher temperature again and an additional peak at about $680^{\circ} \mathrm{C}$ became more evident. This high temperature peak might be attributed to the reduction of Co-Mn mixed oxide due to the sintering of catalyst in absence of $\mathrm{Mg}$. The possible reason is that the existence of $\mathrm{Mg}$ could suppress the sintering and improve the dispersion of the active substance.

Oxygen normally played a very important role in the decomposition of methane according to the catalytic mechanism [20]. As such, the oxygen states on the catalysts herein were investigated by XPS characterization and the binding energies of O1s were given in Figure 5. Generally, there are three different types of oxygen in the catalysts with binding energy of O1s electrons, 529.0-530.0 eV, 531.3-531.9 eV, and $532.7-533.5 \mathrm{eV}$, which could be ascribed to lattice oxygen $\left(\mathrm{O}_{\mathrm{a}}\right)$, surface adsorbed oxygen $\left(\mathrm{O}_{\mathrm{b}}\right)$, and oxygen bonded in $\mathrm{OH}$ group $\left(\mathrm{O}_{\mathrm{c}}\right)$, respectively [21-23]. In case of our catalysts (see Figure 5), oxygen with binding energy of 529.5-530.3 eV was the most intensive form and could be assigned to the lattice oxygen [22]. And oxygen species with binding energy of $531.0-531.5 \mathrm{eV}$ can be attributed to the surface adsorbed oxygen $\left(\mathrm{O}_{\mathrm{b}}\right)$ which could be considered the most active oxygen [24]. The percentage of $\mathrm{O}_{b}$ in total surface oxygen is listed in Table 2, from which we could clearly notice the tendency that $\mathrm{O}_{\mathrm{b}}$ decreased with the introduction of $\mathrm{Co}$, especially for the Mg-free one. In other words, the magnesium was necessary for keeping a certain amount of surface active oxygen possibly due to its well electronic donation property as a typical alkali earth metal. At last, oxygen with binding energy of 532.1-532.9 eV was originated from carbonated species or molecular absorbed water [25].

The catalytic activities of the $\mathrm{Co}_{x} \mathrm{Mg}_{6-x} \mathrm{Mn}_{2} \mathrm{LDO}$ samples derived from $\mathrm{LDH}$ precursors in methane total oxidation tested within the temperature range of $330-600^{\circ} \mathrm{C}$ are shown in Figure 6, where the methane conversion is plotted as a function of the reaction temperature. As shown in Figure 6, it could be clearly observed that the $T_{90}$ (defined as $90 \%$ methane conversion) went down with the increase of Co content at first and then increased for 


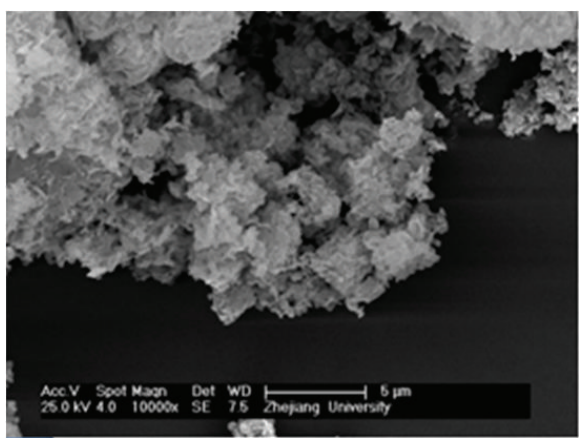

(a)

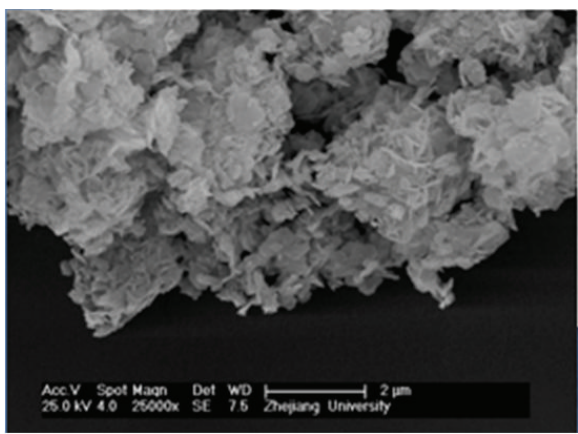

(c)

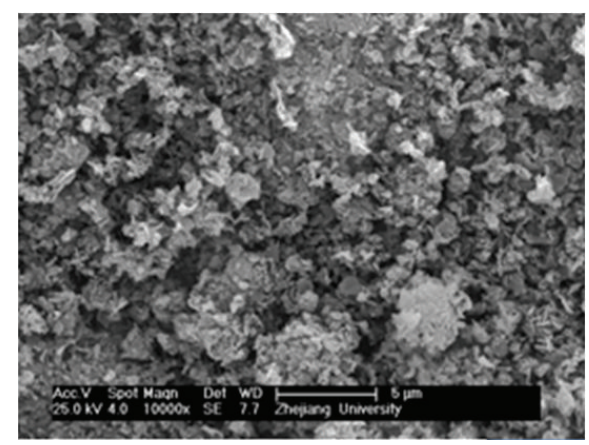

(b)

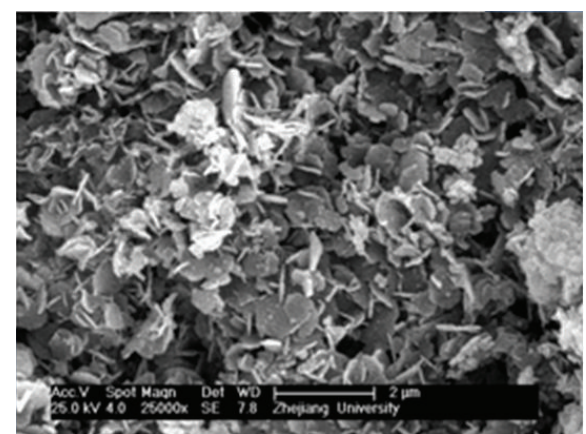

(d)

FIGURE 3: SEM images of $\mathrm{Co}_{x} \mathrm{Mg}_{6-x} \mathrm{Mn}_{2} \mathrm{LDH}$ precursors (a) and (c), $x=4.5$, and (b) and (d), $x=6$.

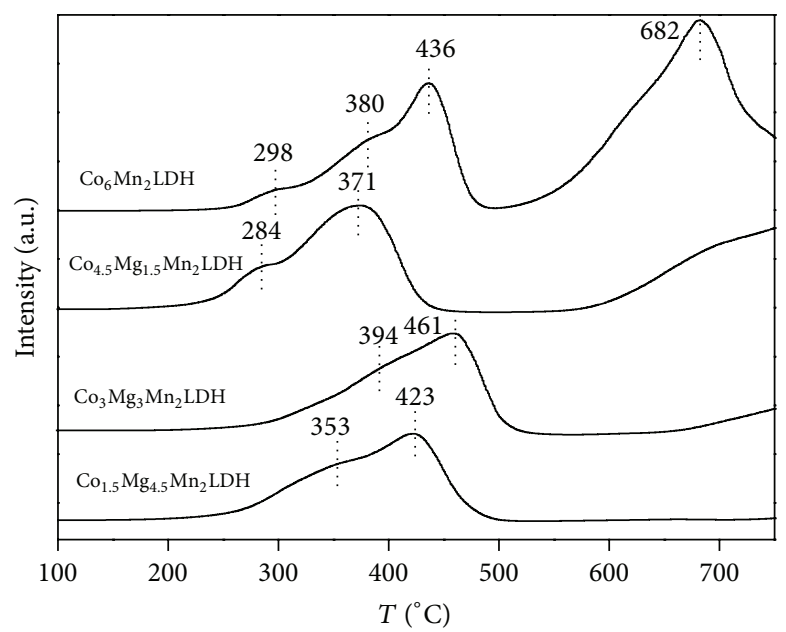

FIGURE 4: $\mathrm{H}_{2}$-TPR patterns of $\mathrm{Co}_{x} \mathrm{Mg}_{6-x} \mathrm{Mn}_{2} \mathrm{LDO}$ samples.

the $\mathrm{Co}_{6} \mathrm{Mn}_{2} \mathrm{LDO}$ sample. The $\mathrm{Co}_{4.5} \mathrm{Mg}_{1.5} \mathrm{Mn}_{2} \mathrm{LDO}$ catalyst showed the best performance with the $T_{90}=485^{\circ} \mathrm{C}$. This result was in agreement with our previous $\mathrm{H}_{2}-\mathrm{TPR}$ characterization where $\mathrm{Co}_{4.5} \mathrm{Mg}_{1.5} \mathrm{Mn}_{2} \mathrm{LDO}$ exhibits the best low-temperature reducibility. As we know, active oxygen was a critical factor for the catalytic oxidation reaction. The various valences of transition metal Co could supply abundant active oxygen in the catalysts, so the activity improved with the increase of Co at first, but when $\mathrm{Mg}$ is totally substituted by Co, the activity decreases because $\mathrm{Mg}$ could act as an electronic promoter in the catalysts to guarantee the oxygen mobility which was of great importance for the catalytic oxidation reactions. The enhanced oxygen mobility after $\mathrm{Ca}$-doping was reported in the literatures, which might indirectly support our assumption $[24,26]$.

\section{Conclusions}

A series of $\mathrm{Co} / \mathrm{Mg}-\mathrm{Mn}$ mixed oxide based catalysts were prepared via the calcination of layered double hydroxides with $(\mathrm{Co}+\mathrm{Mg}) / \mathrm{Mn}$ ratio at 3 and $\mathrm{Co} / \mathrm{Mg}$ ratio from $1.5 / 4.5$ 
TABLE 2: The amount of the surface elements of $\mathrm{Co}_{x} \mathrm{Mg}_{6-x} \mathrm{Mn}_{2} \mathrm{LDO}$.

\begin{tabular}{|c|c|c|c|c|c|}
\hline Sample & Co $(\%)$ & $\operatorname{Mg}(\%)$ & $\mathrm{Mn}(\%)$ & $\mathrm{O}(\%)$ & $\mathrm{O}_{\mathrm{b}} / \mathrm{O}_{\text {total }}$ \\
\hline $\mathrm{Co}_{x} \mathrm{Mg}_{6-x} \mathrm{Mn}_{2} \mathrm{LDO} x=1.5$ & 5.3 & 27.8 & 7.4 & 59.5 & 23.45 \\
\hline $\mathrm{Co}_{x} \mathrm{Mg}_{6-x} \mathrm{Mn}_{2} \mathrm{LDO} x=3$ & 11.3 & 19.6 & 8.5 & 60.6 & 22.59 \\
\hline $\mathrm{Co}_{x} \mathrm{Mg}_{6-x} \mathrm{Mn}_{2} \mathrm{LDO} x=4.5$ & 16.4 & 12.6 & 9.6 & 61.4 & 18.70 \\
\hline $\mathrm{Co}_{x} \mathrm{Mg}_{6-x} \mathrm{Mn}_{2} \mathrm{LDO} x=6$ & 21.3 & 0 & 12.5 & 66.2 & 13.12 \\
\hline
\end{tabular}

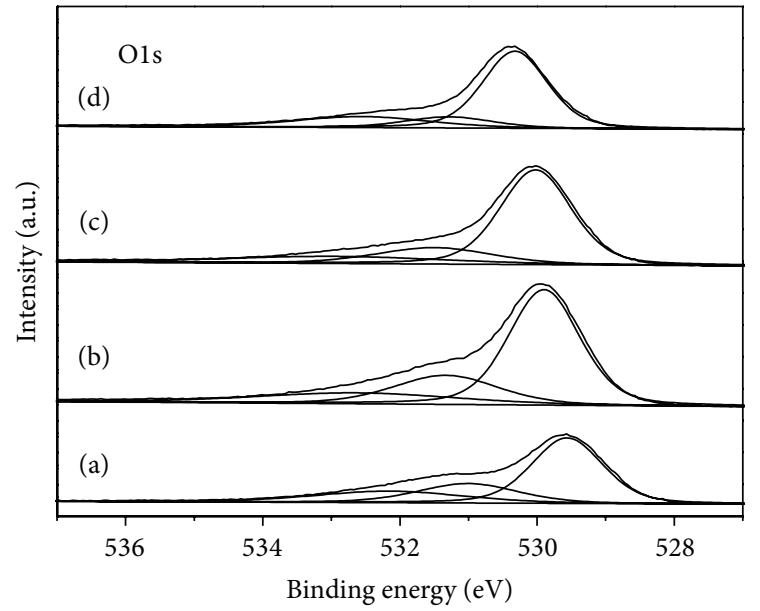

FIGURE 5: O1s XPS patterns of $\mathrm{Co}_{x} \mathrm{Mg}_{6-x} \mathrm{Mn}_{2} \mathrm{LDO}$ samples: (a) $x=$ 1.5 , (b) $x=3$, (c) $x=4.5$, and (d) $x=6$.

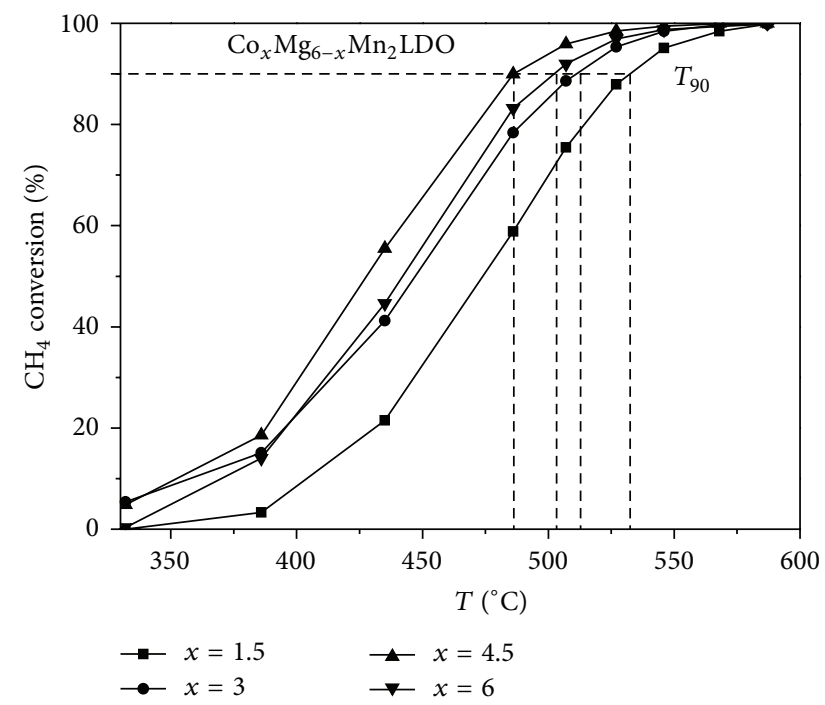

FIGURE 6: Catalytic activity of $\mathrm{Co}_{x} \mathrm{Mg}_{6-x} \mathrm{Mn}_{2} \mathrm{LDO}$ samples ( $1 \% \mathrm{vol}$. $\mathrm{CH}_{4}, 10 \%$ vol. $\mathrm{O}_{2}$, GHSV $=25000 \mathrm{~h}^{-1}$ ).

to $6 / 0$, respectively. And then these catalysts were characterized by various methods and tested for their activities for methane catalytic combustion. The typical LDH lamellar structures were identified by X-ray diffraction except for the last $\mathrm{Co}_{6} \mathrm{Mn}_{2} \mathrm{LDH}$ sample. But spinel structures were formed in all samples after calcination. The catalytic activities of the prepared catalysts expressed as the methane conversion decreased in the following sequence: $\mathrm{Co}_{4.5} \mathrm{Mg}_{1.5} \mathrm{Mn}_{2} \mathrm{LDO}$
$>\mathrm{Co}_{6} \mathrm{Mn}_{2} \mathrm{LDO}>\mathrm{Co}_{3} \mathrm{Mg}_{3} \mathrm{Mn}_{2} \mathrm{LDO}>\mathrm{Co}_{1.5} \mathrm{Mg}_{4.5} \mathrm{Mn}_{2} \mathrm{LDO}$. Though the addition of Co would increase the redox ability of the catalyst, a certain amount of magnesium was necessary for high activity. Magnesium oxide would be beneficial to the dispersion of the cobalt and manganese mixed oxides. Furthermore, the existence of $\mathrm{Mg}$ could reduce the surface area loss after calcination and increase the surface active oxygen content.

\section{Conflict of Interests}

The authors declare that there is no conflict of interests regarding the publication of this paper.

\section{Acknowledgment}

This work is financially supported by Zhejiang Provincial "151" Talents Program.

\section{References}

[1] J. Yin, S. Su, X. X. Yu, and Y. Weng, "Thermodynamic characteristics of a low concentration methane catalytic combustion gas turbine," Applied Energy, vol. 87, no. 6, pp. 2102-2108, 2010.

[2] H. Arai, T. Yamada, K. Eguchi, and T. Seiyama, "Catalytic combustion of methane over various perovskite-type oxides," Applied Catalysis, vol. 26, pp. 265-276, 1986.

[3] P. Gélin and M. Primet, "Complete oxidation of methane at low temperature over noble metal based catalysts: a review," Applied Catalysis B: Environmental, vol. 39, no. 1, pp. 1-37, 2002.

[4] D. Ciuparu, M. R. Lyubovsky, E. Altman, L. D. Pfefferle, and A. Datye, "Catalytic combustion of methane over palladium-based catalysts," Catalysis Reviews: Science and Engineering, vol. 44, no. 4, pp. 593-649, 2002.

[5] S. Tanasoi, N. Tanchoux, A. Urdă et al., "New Cu-based mixed oxides obtained from LDH precursors, catalysts for methane total oxidation," Applied Catalysis A: General, vol. 363, no. 1-2, pp. 135-142, 2009.

[6] L. Hu, Q. Peng, and Y. Li, "Selective synthesis of $\mathrm{Co}_{3} \mathrm{O}_{4}$ nanocrystal with different shape and crystal plane effect on catalytic property for methane combustion," Journal of the American Chemical Society, vol. 130, no. 48, pp. 16136-16137, 2008.

[7] J. Kirchnerova, M. Alifanti, and B. Delmon, "Evidence of phase cooperation in the $\mathrm{LaCoO}_{3}-\mathrm{CeO}_{2}-\mathrm{Co}_{3} \mathrm{O}_{4}$ catalytic system in relation to activity in methane combustion," Applied Catalysis A: General, vol. 231, no. 1-2, pp. 65-80, 2002.

[8] W. B. Li, W. B. Chu, M. Zhuang, and J. Hua, "Catalytic oxidation of toluene on $\mathrm{Mn}$-containing mixed oxides prepared in reverse microemulsions," Catalysis Today, vol. 93-95, pp. 205-209, 2004 . 
[9] W. B. Li, J. X. Wang, and H. Gong, "Catalytic combustion of VOCs on non-noble metal catalysts," Catalysis Today, vol. 148, no. 1-2, pp. 81-87, 2009.

[10] M. R. Morales, B. P. Barbero, and L. E. Cadús, "Total oxidation of ethanol and propane over $\mathrm{Mn}-\mathrm{Cu}$ mixed oxide catalysts," Applied Catalysis B: Environmental, vol. 67, no. 3-4, pp. 229-236, 2006.

[11] F. Zhang, X. Xiang, F. Li, and X. Duan, "Layered double hydroxides as catalytic materials: recent development," Catalysis Surveys from Asia, vol. 12, no. 4, pp. 253-265, 2008.

[12] K. Bahranowski, E. Bielańska, R. Janik, T. Machej, and E. M. Serwicka, "LDH-derived catalysts for complete oxidation of volatile organic compounds," Clay Minerals, vol. 34, no. 1, pp. 67-77, 1999.

[13] Q. Li, M. Meng, H. Xian et al., "Hydrotalcite-derived $\mathrm{Mn}_{x} \mathrm{Mg}_{3-x} \mathrm{AlO}$ catalysts used for soot combustion, $\mathrm{NO}_{x}$ storage and simultaneous soot- $\mathrm{NO}_{x}$ removal," Environmental Science \& Technology, vol. 44, no. 12, pp. 4747-4752, 2010.

[14] F. Kovanda, T. Rojka, J. Dobešová et al., "Mixed oxides obtained from Co and Mn containing layered double hydroxides: preparation, characterization, and catalytic properties," Journal of Solid State Chemistry, vol. 179, no. 3, pp. 812-823, 2006.

[15] P. Peshev, A. Toshev, and G. Gyurov, "Preparation of highdispersity $\mathrm{MCo}_{2} \mathrm{O}_{4}(\mathrm{M}=\mathrm{Mg}, \mathrm{Ni}, \mathrm{Zn})$ spinels by thermal dissociation of coprecipitated oxalates," Materials Research Bulletin, vol. 24, no. 1, pp. 33-40, 1989.

[16] X. Yang, X. Xia, and N. Wu, "Molybdate anion pillared Mg-Al hydrotalcite as precursors for HDS catalysts I. Chemical state and dispersity of $\mathrm{MoO}_{3}$ in $\mathrm{MoO}_{3} / \mathrm{Mg}(\mathrm{Al}) \mathrm{O}$," Chinese Journal of Catalysis, vol. 22, no. 4, pp. 358-360, 2001.

[17] Q. Miao, G. Xiong, S. Sheng, W. Cui, and X. Guo, "The oxidative transformation of methane over the nickel-based catalysts modified by alkali metal oxide and rare earth metal oxide," Studies in Surface Science and Catalysis, vol. 101, pp. 453462, 1996.

[18] L. Obalová, K. Pacultová, J. Balabánová et al., "Effect of $\mathrm{Mn} / \mathrm{Al}$ ratio in $\mathrm{CoMnAl}$ mixed oxide catalysts prepared from hydrotalcite-like precursors on catalytic decomposition of $\mathrm{N}_{2} \mathrm{O}$," Catalysis Today, vol. 119, no. 1-4, pp. 233-238, 2007.

[19] L. Obalová, K. Karásková, K. Jirátová, and F. Kovanda, “Effect of potassium in calcined Co-Mn-Al layered double hydroxide on the catalytic decomposition of $\mathrm{N}_{2} \mathrm{O}$," Applied Catalysis B: Environmental, vol. 90, no. 1-2, pp. 132-140, 2009.

[20] T. Ito, T. Watanabe, T. Tashiro, and K. Toi, "Reaction of preadsorbed methane with oxygen over magnesium oxide at low temperatures," Journal of the Chemical Society, vol. 85, no. 8, pp. 2381-2395, 1989.

[21] M. Kang, E. D. Park, J. M. Kim, and J. E. Yie, "Manganese oxide catalysts for NOx reduction with NH3 at low temperatures," Applied Catalysis A: General, vol. 327, no. 2, pp. 261-269, 2007.

[22] A. Machocki, T. Ioannides, B. Stasinska et al., "Manganeselanthanum oxides modified with silver for the catalytic combustion of methane," Journal of Catalysis, vol. 227, no. 2, pp. 282296, 2004.

[23] E. Ksepko, E. Talik, A. Ratuszna, A. Molak, Z. Ujma, and I. Gruszka, "XPS examination of newly obtained $\left(\mathrm{Na}_{0.5} \mathrm{~Pb}_{0.5}\right)$ $\left(\mathrm{Mn}_{0.5} \mathrm{Nb}_{0.5}\right) \mathrm{O}_{3}$ ceramics," Journal of Alloys and Compounds, vol. 386, no. 1-2, pp. 35-42, 2005.

[24] T. Gu, R. Jin, Y. Liu, H. Liu, X. Weng, and Z. Wu, "Promoting effect of calcium doping on the performances of $\mathrm{MnO}_{x} / \mathrm{TiO}_{2}$ catalysts for $\mathrm{NO}$ reduction with $\mathrm{NH}_{3}$ at low temperature," Applied Catalysis B: Environmental, vol. 129, pp. 30-38, 2013.
[25] K. Jirátová, J. Mikulová, J. Klempa, T. Grygar, Z. Bastl, and F. Kovanda, "Modification of Co-Mn-Al mixed oxide with potassium and its effect on deep oxidation of VOC," Applied Catalysis A: General, vol. 361, no. 1-2, pp. 106-116, 2009.

[26] H. Song and U. S. Ozkan, "Changing the oxygen mobility in $\mathrm{Co} / \mathrm{Ceria}$ catalysts by $\mathrm{Ca}$ incorporation: implications for ethanol steam reforming," The Journal of Physical Chemistry A, vol. 114, no. 11, pp. 3796-3801, 2010. 

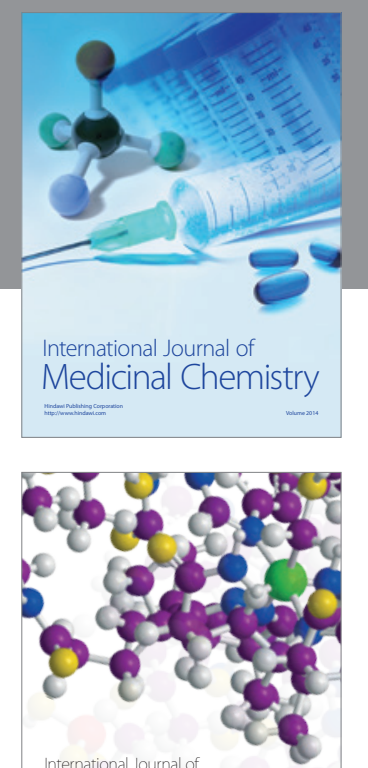

\section{Carbohydrate} Chemistry

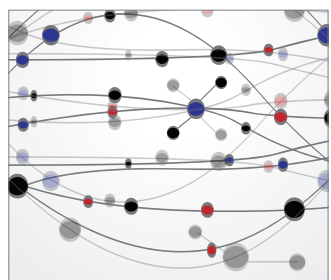

The Scientific World Journal
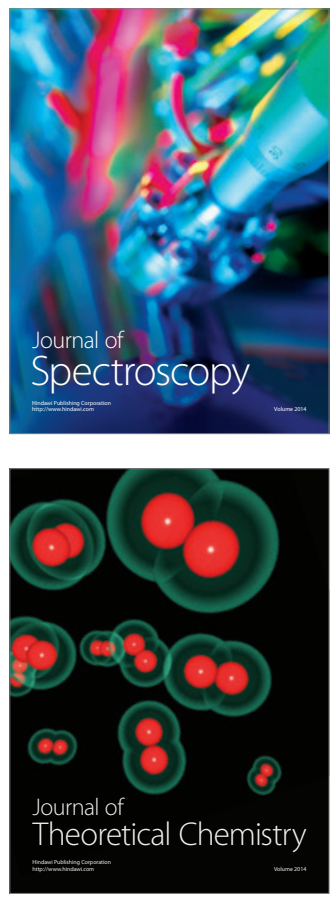
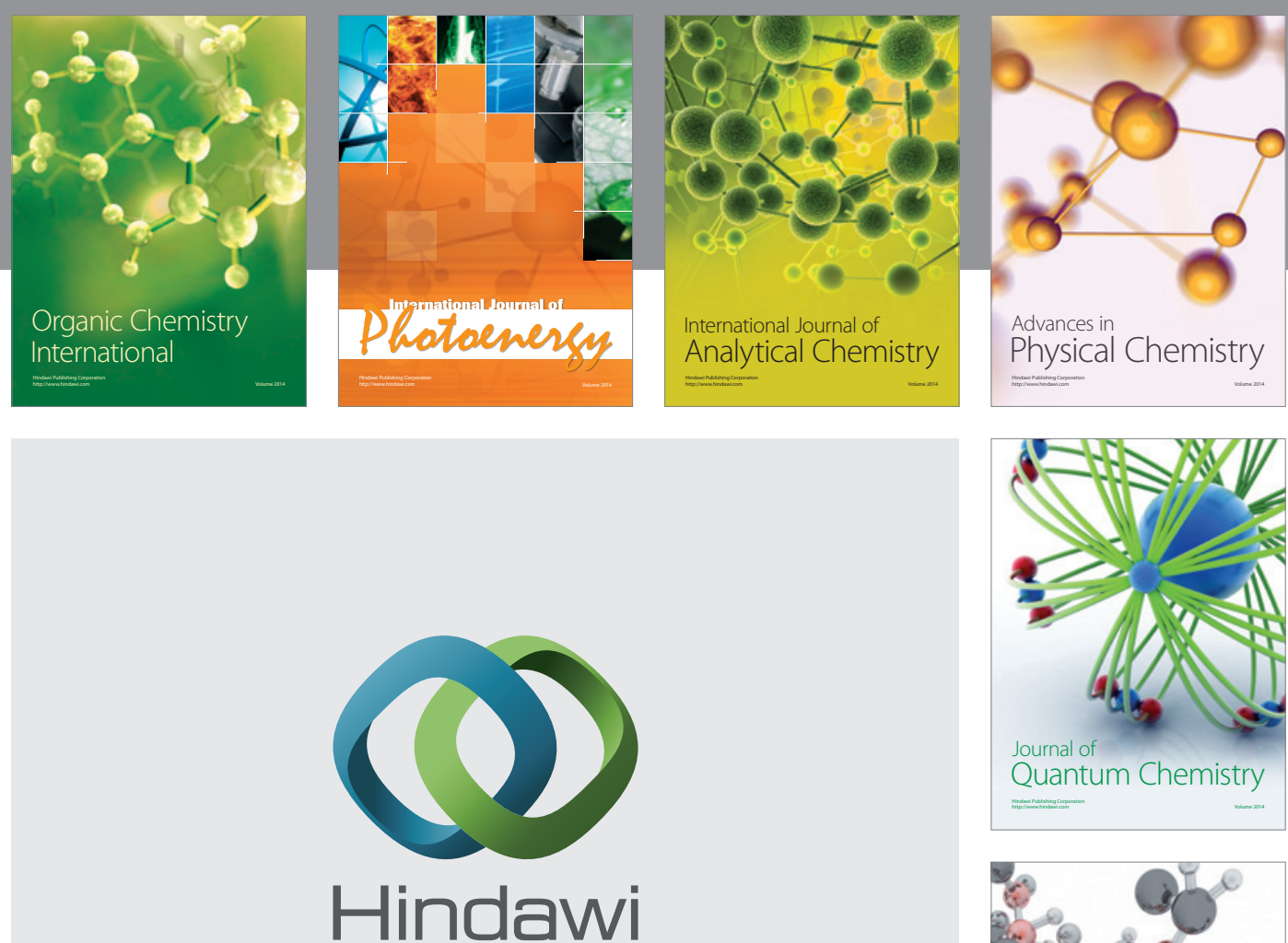

Submit your manuscripts at

http://www.hindawi.com

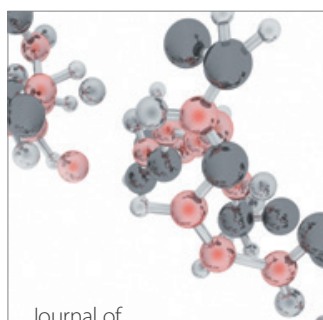

Analytical Methods

in Chemistry

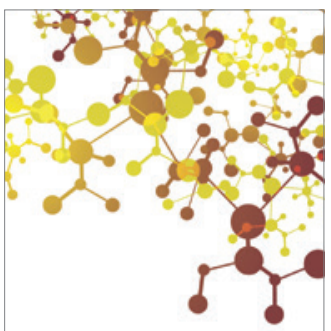

Journal of

Applied Chemistry

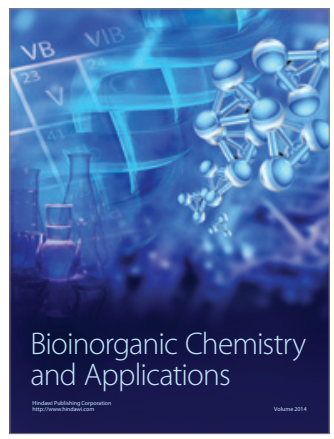

Inorganic Chemistry
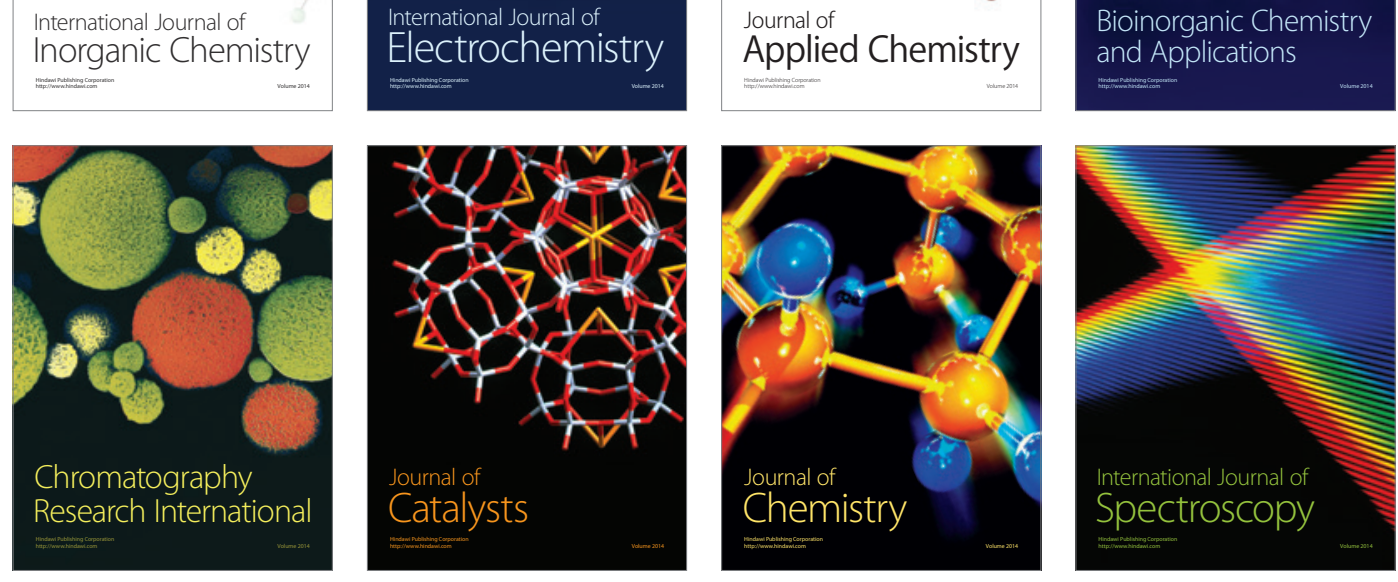